\title{
Ecological studies on Aerangis biloba (Lindl.) Schltr. (Orchidaceae) in NACGRAB field gene bank, southwestern Nigeria
}

\author{
Temitope Israel Borokini ${ }^{1} \&$ Adedotun Onoyinka Afolayan ${ }^{2}$ \\ 1,2 National Centre for Genetic Resources and Biotechnology (NACGRAB), P.M.B 5382, Moor Plantation, Ibadan, Oyo State 23402, \\ Nigeria \\ Email: ${ }^{1}$ tbisrael@gmail.com (corresponding author), ${ }^{2}$ onoyinka@yahoo.com
}

\begin{abstract}
Aerangis biloba (Lindl.) Schltr. belongs to the family Orchidaceae, which is listed as threatened under the Appendix II of the CITES. This study was conducted to estimate the population and distribution of Aerangis biloba in the field by National Centre for Genetic Resources and Biotechnology (NACGRAB), Ibadan, southwestern Nigeria. Twenty five sample plots of $50 \mathrm{~m}$ by $50 \mathrm{~m}$ each along line transects were randomly chosen and studies were carried out on them. The results were correlated with the factors that affect the distribution and survival of $A$. biloba. A total of 129 specimens of $A$. biloba were observed within the study area, giving a population density of 5.16 orchids per $\mathrm{m}^{2}$. This indicates that the species is abundant in the sampled area, as a result of good population of the selected phorophytes. The analysis of the data indicated a high correlation between and among the plots $(P=0.0003)$. A. biloba was observed only on nine trees among over 160 trees present in the sampling area, suggesting that these nine trees could act as phorophyte for A. biloba of which, Irvingia gabonensis and Irvingia wombulu harbored the highest number of orchids. The paper gives a synopsis of the economic and ecological significance of orchids It also recommends controlled harvesting, reduced deforestation and establishment of orchid gardens as some of the effective ways of enhancing orchid conservation in Nigeria.
\end{abstract}

Keywords: Aerangis biloba, epiphytes, field gene bank NACGRAB, phorophytes.

Date of publication (online): 26 September 2012

Date of publication (print): 26 September 2012

ISSN 0974-7907 (online) | 0974-7893 (print)

Editor: Pankaj Kumar

Manuscript details:

Ms \# 02728

Received 15 March 2011

Final received 27 February 2012

Finally accepted 05 September 2012

Citation: Borokini, T.I. \& A.O. Afolayan (2012). Ecological studies on Aerangis biloba (Lindl.) Schltr. (Orchidaceae) in NACGRAB field gene bank, southwestern Nigeria. Journal of Threatened Taxa 4(11): 3075-3081.

Copyright: () Temitope Israel Borokini \& Adedotun Onoyinka Afolayan 2012. Creative Commons Attribution 3.0 Unported License. JoTT allows unrestricted use of this article in any medium for non-profit purposes, reproduction and distribution by providing adequate credit to the authors and the source of publication.

\section{OPEN ACCESS | FREE DOWNLOAD}

The family Orchidaceae comprises over 850 genera and an estimated 25,000 species representing about $10 \%$ of the world's flowering plants and the largest family in species number (Roberts \& Dixon 2008). The African continent harbours around 2,400 orchid species (Madison 1977). Of the 25,000 known orchid species, more than $70 \%$ are thought to live as epiphytes in tree canopies (Gravendeel et al. 2004). An epiphyte is considered to be a plant living on another plant or sometimes on other objects above ground surface and growing either partly or entirely in the air, into suspended soils, or in woody debris (Richards 1996; Moffett 2000). Barkman (1958) coined the term 'phorophyte' for the plants that support epiphytes. Orchidaceae contains $60 \%$ of all epiphytic species and 10 times as many epiphyte species as any other family of vascular plants (Kres 1986).

The genus Aerangis has many species in Africa and Madagascar with strikingly pretty flowers. Most African epiphytic orchids were classified in the genus Angraecum in the mid $18^{\text {th }}$ century and Lindley described this species as the 'two-lobed Angurek' - Angraecum bilobum (Stewart 1975). The name was chosen to describe the leaf apex, which is often conspicuously bilobed. Although, Reichenbach had established the genus Aerangis in 1865, it was not until 1914 that Schlechter transferred this species into the genus Aerangis (Stewart 1975).

A study of the notes attached to the herbarium specimens of Aerangis biloba at Kew revealed that most have been collected in dense forest in the Ivory Coast and on isolated trees in the savannah areas of northern Nigeria. They are found in thickets, forest edges and small patches of woodlands as well as high forests. Many have been observed growing among plantation crops and frequently on village trees. Citrus, mango, orange, palm and coffee trees have been recorded as 
actual hosts for this epiphyte (Stewart 1975). Most of the plants collected in flower have been found in July and August, which is towards the end of the main rainy season in West Africa. This indicates that the plants require plenty of water prior to blooming and have a specific and predictable blooming season that corresponds to seasonal rainfall and coordination of the life-cycle of its pollinators. It thrives when planted in a slatted basket with large pieces of bark (Stewart 1975).

In terms of their ecological significance, orchids are a part of the autotrophic web of organisms, absorbing energy and converting it to food, part of which is transferred along a complex ecological food web when living in association with other living organisms. The flowers are highly attractive to nectar-feeding insects and birds. Furthermore, epiphytic orchids contribute to the complexity, structure and function of the canopy, and are important components in terms of both biomass and species diversity; they interact with vast numbers of canopy invertebrates, as well as many vertebrate species (Nadkarni 1984; Ellwood et al. 2002; Wolf \& Flamenco 2003; Gravendeel et al. 2004; Monteiro et al. 2009).

As a result of the threat from over-collecting all orchids have been placed on Appendix II or higher of the Convention on International Trade in Endangered Species (CITES). Despite this protection, the ongoing general decrease in the number and size of orchid populations is mainly due to the loss and degradation of their habitats (Koopowitz et al. 2003). Because orchids are susceptible to human activities, they have been proposed as indicators of levels of human disturbance and overall ecosystem health (Turner et al; 1994; Benzing 1998).

In Nigeria, very little attention has been given to the study of orchids. Worse still, there are no accurate surveys on the diversity, population and conservation status of orchids. It has been reported that the orchids Habenaria nigerica, and Diaphananthe dorotheae are exclusive endemics for Nigeria; Segerback (1983) described 104 species of orchids for Nigeria, but Jayeola (1991) encountered over 400 species for the country indicating a richer diversity of orchid species than was previously thought. Since very few people are involved in orchid cultivation in Nigeria, most of the orchid flowers harvested for ornamental purpose comes from the wild. With increasing anthropogenic disturbances, epiphyte species richness declines (Hietz 1999; Kromer \& Gradstein 2003) and community composition changes (Werner et al. 2005). Therefore, this study was conducted to assess the population of Aerangis biloba in the field gene bank of National Centre for Genetic Resources and Biotechnology (NACGRAB), Ibadan, southwestern Nigeria with the view of studying the effects of the ecological factors on the population and distribution of this orchid within the gene bank. This study is part of the proposed extensive study on the orchid survey in Nigeria.

\section{Materials and Methods \\ Study Area}

The field gene bank of National Centre for Genetic Resources and Biotechnology (NACGRAB) was established in 1987, as an ex situ collection site for indigenous recalcitrant plants in Nigeria. It is about 12ha wide, lying on the latitude $7^{0} 22^{\prime}$ North of the equator and longitude $3^{0} 50^{\prime}$ East of the Greenwich Meridian. The Field Gene bank of NACGRAB contains a large variety of plants with diverse growth forms. According to Borokini et al. (2010), 361 plants have been identified in the field gene bank, comprising 160 trees, 119 herbs, 55 shrubs and 27 vines. Some of the plants established on the field gene bank are in plantations, while others are scattered within the field. The climate of the study area is characterized by high temperature and a bimodal rainfall pattern. The annual total and mean rainfall was 1,435.8 and $99.87 \mathrm{~mm}$ respectively for year 2008. Rainfall for the area spans from February to December, with peak in September $(289.9 \mathrm{~mm})$; no rainfall was recorded for November. The mean annual minimum and maximum temperatures were $24.57^{\circ} \mathrm{C}$ and $32.1^{\circ} \mathrm{C}$ respectively for 2008, while the relative humidity was lowest at $53 \%$ in January and highest at $92 \%$ in August. Agrometeorological records from 1979 to 2008 show insignificant difference in the data taken for rainfall, temperature and relative humidity. Image 1 shows the location of the study area within Nigeria.

\section{Data collection and analysis}

This survey was carried out between 1 and 5 September 2010. It involves an enumeration of the orchids within $50 \times 50 \mathrm{~m}$ plots laid along line transects within the field gene bank at an interval of $25 \mathrm{~m}$. Twenty five sample plots were laid; making a total of sampled 


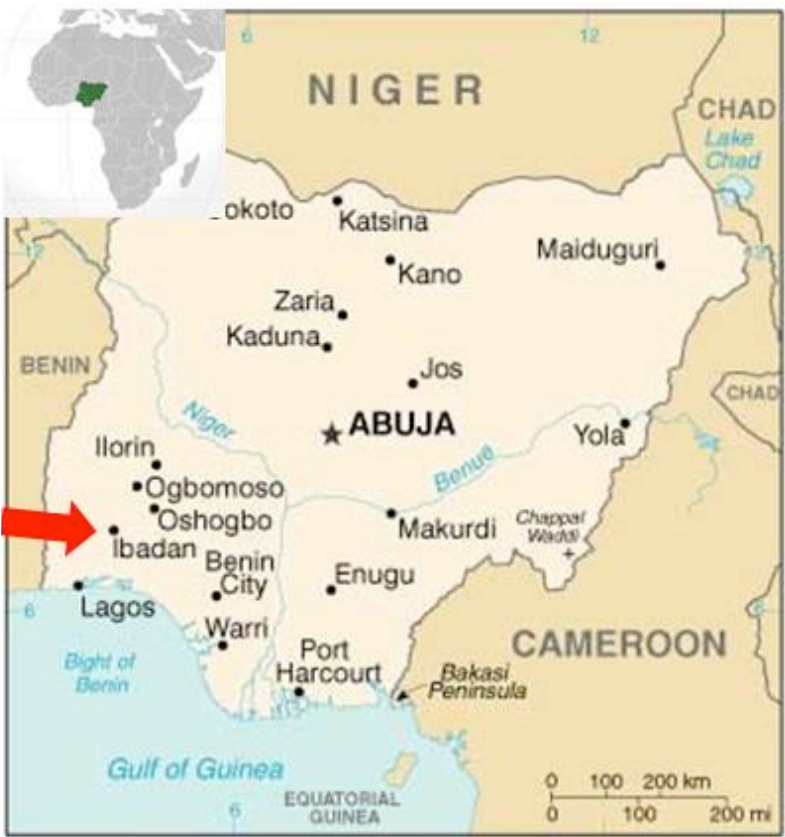

Image 1. Map of Nigeria showing the location of study area

area to be $6.25 \mathrm{ha}$ that is $52.08 \%$ of the total field gene bank area. Furthermore, the phorophytes on which the orchids were found were noted, the population of the phorophytes and the height of the orchids on the phorophytes was also documented. Photographs of A. biloba on the phorophytes were taken. The results were subjected to statistical analysis to determine the population density, analysis of variance (ANOVA) and test of significance using PAST Statistical software (Hammer et al. 2001). The population density within each plot was calculated as the number of occurrence divided by the area of the plot in sq.m.

\section{Results}

A total of 129 Aerangis biloba were identified in the 25 plots sampled within the field gene bank of NACGRAB, Ibadan, Nigeria; giving a population density of 5.16 (Table 1). This result indicates that the species is abundant in the field gene bank. Table 1 shows the occurrences of the orchid in each of the sampled plot and the trees identified in each of the plots. Furthermore, the phorophytes for the epiphytic orchid include Irvingia gabonensis, Citrus spp, Spondias mombin, Irvingia wombulu, Tecoma stans, Azadirachta indica, Psidium guajava, Albizia odoratissima and Mangifera indica. Table 2 shows the population of each of the identified phorophytes for this orchid species within the sampled area of the field gene bank; while images 2-3 are the photographs that illustrate the orchids growing on the phorophytes within the field genebank. The epiphytes were attached to the phorophytes either on the main trunk or the branches. The orchid population on each of the phorophyte ranges from one to seven per plant. $I$. gabonensis had up to seven orchids per phorophyte,

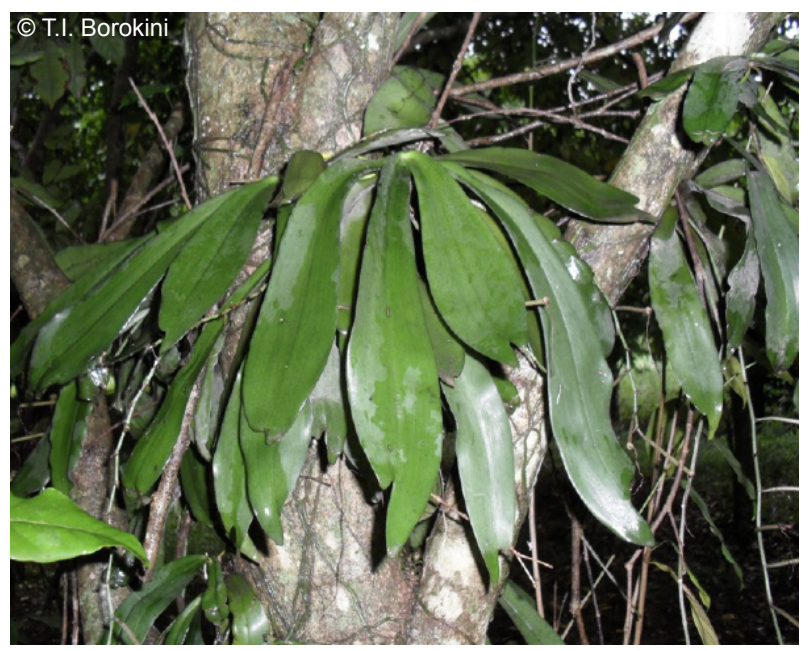

Image 2. Aerangis biloba growing on the stem of Irvingia gabonensis

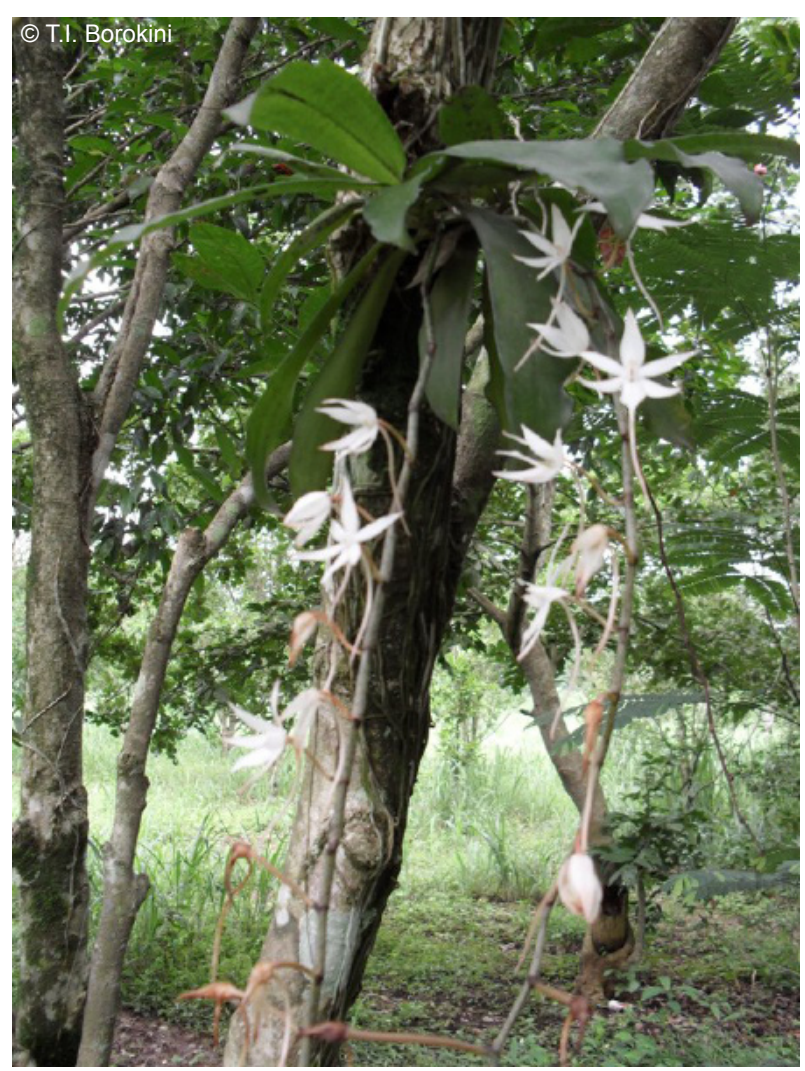

Image 3. Aerangis biloba with whitish flowers 
Table 1. Occurrences of Aerangis biloba within the 25 plots sampled

\begin{tabular}{|c|c|c|c|}
\hline Plots & Occurrences & Density & Trees identified within each plot \\
\hline 1 & 21 & 0.0336 & Irvingia gabonensis, Adansonia digitata, Psidium guajava \\
\hline 2 & 18 & 0.0288 & $\begin{array}{l}\text { Irvingia gabonensis, Kigelia africana, Terminalia ivorensis, Nauclea didderrichii, Mangifera indica, } \\
\text { Blighia sapida }\end{array}$ \\
\hline 3 & 11 & 0.0176 & $\begin{array}{l}\text { Irvingia gabonensis, Kigelia africana, Terminalia ivorensis, Terminalia superba, Spondias mombin, } \\
\text { Pentachelthra macrophylla, Dacryodes edulis, Polyathia longiflora }\end{array}$ \\
\hline 4 & 0 & 0 & $\begin{array}{l}\text { Ficus iteophylla, Ficus mucoso, Treculia africana, Pterocarpus santalinioides, Tabebuia rosea, } \\
\text { Samanea saman, Khaya grandifoliola, Synsepalum dulcificum }\end{array}$ \\
\hline 5 & 1 & 0.0016 & $\begin{array}{l}\text { Citrus sp., Musa sp., Entandrophragma cylindricum, Harrisonia abyssinica, Costus afer, Terminalia } \\
\text { catappa }\end{array}$ \\
\hline 6 & 0 & 0 & Terminalia catappa, Lagerstroemia speciosa, Hibiscus rosa-sinensis, Melicia excelsa, Hura crepitans \\
\hline 7 & 2 & 0.0032 & $\begin{array}{l}\text { Mangifera indica, Funtumia elastica, Eucalyptus camaldulensis, Terminalia superba, Khaya } \\
\text { grandifoliola, Dalbergia sissoo }\end{array}$ \\
\hline 8 & 6 & 0.0096 & Mansonia altissima, Mangifera indica, Cedrela odorata, Leucaena leucocephala \\
\hline 9 & 0 & 0 & Elaeis guineensis, Cola millenii, Cola gigantea, Kigelia africana, Musa sp., Terminalia superba \\
\hline 10 & 9 & 0.0144 & $\begin{array}{l}\text { Citrus sp., Tecoma stans, Enterolobium cyclocarpum, Nauclea diderrichi, Anthonotha macrophylla, } \\
\text { Casuarina equisetifolia }\end{array}$ \\
\hline 11 & 16 & 0.0256 & $\begin{array}{l}\text { Citrus sp., Musa sp., Enterolobium cyclocarpum, Theobroma cacao, Gliricidia sepium, Klainedoxa } \\
\text { gabonensis }\end{array}$ \\
\hline 12 & 0 & 0 & $\begin{array}{l}\text { Hollarhena floribunda, Delonix regia, Eugenia vitiflora, Hura crepitans, Calophyllum inophyllum, } \\
\text { Anacardium occidentale }\end{array}$ \\
\hline 13 & 1 & 0.0016 & Albizia odoratissima, Tectona grandis, Gmelina arborea, Terminalia superba, \\
\hline 14 & 0 & 0 & $\begin{array}{l}\text { Newbouldia laevis, Afzelia africana, Monodora myristica, Acacia nilotica, Tetrapleura tetraptera, } \\
\text { Plumeria rubra }\end{array}$ \\
\hline 15 & 1 & 0.0016 & $\begin{array}{l}\text { Tecoma stans, Rauvolfia vomitoria, Blighia sapida, Parkia biglobosa, Cedrela odorata, Jatropha } \\
\text { curcas }\end{array}$ \\
\hline 16 & 1 & 0.0016 & Citrus sp., Treculia africana, Lecaniodiscus cupanioides, Ceiba petandra, Persea americana \\
\hline 17 & 2 & 0.0032 & $\begin{array}{l}\text { Azadirachta indica, Morinda lucida, Khaya senegalensis, Griffonia simplicifolia, Triplochiton } \\
\text { scleroxylon }\end{array}$ \\
\hline 18 & 0 & 0 & $\begin{array}{l}\text { Moringa oleifera, Ficus exasperata, Bombax glabra, Sterculia tragacantha, Syzygium zamarangensis, } \\
\text { Melia azaderach }\end{array}$ \\
\hline 19 & 0 & 0 & $\begin{array}{l}\text { Khaya ivorensis, Artocarpus altilis, Melicia excelsa, Leucaena leucocephala, Daniella ogea, Hevea } \\
\text { brasiliensis }\end{array}$ \\
\hline 20 & 10 & 0.016 & Irvingia wombolu, Chrysophyllum albidum, Carica papaya, Spondias mombin, Mangifera indica \\
\hline 21 & 17 & 0.0272 & Irvingia wombolu, Jatropha curcas, Carica papaya \\
\hline 22 & 12 & 0.0192 & Irvingia wombolu, Cnidoscolus alternifolius, Hevea brasiliensis, Calotropis procera \\
\hline 23 & 1 & 0.0016 & $\begin{array}{l}\text { Albizia odoratissima, Samanea saman, Musa sp., Tamarindus indica, Tetrapleura tetraptera, } \\
\text { Cleistopholis patens }\end{array}$ \\
\hline 24 & 0 & 0 & $\begin{array}{l}\text { Cochlospermum reliogiosum, Terminalia superba, Terminalia ivorensis, Khaya ivorensis, Pinus } \\
\text { caribaea }\end{array}$ \\
\hline 25 & 0 & 0 & $\begin{array}{l}\text { Annona senegalensis, Albizia lebbeck, Acacia auriculiformis, Dalbergia latifolia, Eugenia vitiflora, } \\
\text { Delonix regia, Gmelina arborea }\end{array}$ \\
\hline Total & 129 & 0.2064 & \\
\hline
\end{tabular}

and many of the I. gabonensis stands have A. biloba growing on them. It was also noted that the height of the epiphytes on the phorophytes range from 0.7 to $2.9 \mathrm{~m}$.

The statistical analysis showed that the variation of the occurrence of the orchids within and among the plots are highly significant $(\mathrm{P}=0.0003)$ indicating that the occurrence of the epiphytic orchid is relatively dependent on the availability and abundance of its specific phorophyte. The standard deviation was 6.89 (Table 3 ) and the population density within each plot ranged from 0 to 0.0336 (Table 1), which further shows the interdependency of epiphytic orchids on their corresponding phorophytes. 
Table 2. Phorophytes population in the NACGRAB Field Gene bank

\begin{tabular}{|c|l|l|c|}
\hline & Name of Phorophyte & Plant family & Population \\
\hline 1 & Citrus spp. & Rutaceae & 134 \\
\hline 2 & Irvingia gabonensis & Irvingiaceae & 612 \\
\hline 3 & Irvingia wombulu & Irvingiaceae & 301 \\
\hline 4 & Mangifera indica & Anacardiaceae & 97 \\
\hline 5 & Spondias mombin & Anacardiaceae & 5 \\
\hline 6 & Tecoma stans & Bignoniaceae & 2 \\
\hline 7 & Azadirachta indica & Meliaceae & 16 \\
\hline 8 & Psidium guajava & Myrtaceae & 3 \\
\hline 9 & Albizia odoratissima & Mimosaceae & 18 \\
\hline
\end{tabular}

\section{Discussion}

Aerangis bloba is relatively abundant in the field gene bank due to high population of the preferred phorophytes, which provided medium of establishment. The pollination of the flowers by native moths and spread of the seeds by air currents from tree to tree further promoted the establishment of the orchid in this area. Only nine of the 160 trees in the field gene bank were identified as phorophytes for A. biloba. This indicates that A. biloba, like many other epiphytic orchids, are only able to germinate and survive to reproductive age on certain phorophytes. The occurrence of orchids in a plot increases with increase in the phorophyte population within the plot. This indicates that the occurrence of the orchids is dependent on the phorophytes, therefore, the presence, population and distribution of the phorophytes determines the distribution and the frequency of the orchids within the plots. Likewise, the survival and conservation of the orchids is highly dependent on specific tree species, which act as phorophytes (hosts) for the orchids. This study has, therefore, revealed a significant number of phorophytes for A. biloba. The abundance and distribution of these phorophytes will help in the conservation of this orchid species.

While some previous studies reported little or no phorophyte specificity among some epiphytes (Johansson 1974; Sanford 1974; Todzia 1986;
Ackerman et al. 1989; Zimmerman \& Olmsted 1992; Ackerman et al. 1996); other authors reported phorophyte specificity among some vascular epiphytes (Went 1940; Frei 1973; ter Steege \& Cornelissen 1989; Merwin et al. 2003). Although epiphytes are a significant component of overall plant diversity, relatively little is known about the specificity of the association between epiphytes and their phorophytes. This association is of particular interest since epiphytes are confined to a patchy and discontinuous distribution of suitable substrate. The specificity of the orchidphorophyte relationship may have direct bearing on the abundance of epiphytic taxa, particularly as increasing rates of anthropogenic-related habitat disturbance exacerbate the patchiness of suitable substrate (Trapnell \& Hamrick 2006). Therefore, there is the need to study further the ecological associations between orchids and phorophytes and study the selective nature of epiphytic orchids for phorophytes, with the aim of assessing their conservation status.

Orchids are dependent on their host trees for survival, and hence, deforestation could likely increase the chances of orchids being threatened in their habitats. Riofrio et al. (2007) noted that deforestation practices pose a major threat for the survival of orchids, as they are greatly dependent on the environmental conditions of the forests that sustain them and the host trees on which they grow. In the light of this, Riofrio et al. (2007) advocated for studies on the patterns of spatial distribution and colonization of secondary succession forests regenerated after deforestation. It is therefore, recommended that deforestation should be discouraged, as they do not only cause a lot of environmental damage to the natural ecosystem, but also increase the risk of extinction of orchids that depend on them. It is also interesting to note that as some orchids are considered as threatened, some new species are being discovered such as Vanda longitepala, which was discovered in northern Burma (Roberts et al. 2008). However, such new discoveries would not be possible if the habitats (the forests) have been degraded through deforestation and land use changes.

Table 3. Analysis of the data collected on Aerangis biloba in NACGRAB field gene bank

\begin{tabular}{|l|c|c|c|c|c|}
\hline & Sum of squares & Df & Mean squares & F cal & \\
\hline Between groups & 768.32 & 1 & 768.32 & 15.12 & $0.0003098^{\text {*** }}$ \\
\hline Within groups & 2439.36 & 48 & 50.82 & & \\
\hline
\end{tabular}


As all orchids are considered threatened and extinction of orchids reported in some countries; it should be noted that extinction of orchids have extensive detrimental effects on ecosystem health. The field gene bank has a uniform climatic condition, elevation and altitude most suitable for the colonization of Aerangis biloba. It is essential that continuous management and conservation of the phorophytes in the field gene bank should be undertaken to ensure the survival and sustenance of the epiphytic orchids and their complex ecological relationship with other biotic components of the community. Especially since the selective nature of $A$. biloba for a specific type of phorophyte might be the major factor responsible for their distribution within the gene bank.

From literature studies, it could be noted that overcollection of wild orchids for sale and deforestation are the greatest risk factors for the survival of wild orchid populations (Koopowitz et al. 2003). Therefore, cultivation of orchids should be encouraged, in order to reduce the pressure on the wild collections and at the same time, be a source of income generation and self-employment for interested people, especially the youth, since there is a ready market for orchids and the capital involved is relatively small.

It is also strongly recommended that research attention be given to Nigerian orchids, to conduct a comprehensive survey on their natural distribution, population, the phorophytes of the epiphytic orchids, samples taken and cultures created of their mycorrhizae symbionts and their conservation status.

\section{Conclusion and Recommendation}

Aerangis biloba, like many other orchids, is an important component of a complex ecosystem, and members of its populations as producers of nectar, are fundamental to some complex food webs. This study has revealed that the abundance and conservation of epiphytic orchids, such as $A$. biloba is dependent on the abundance and population of the phorophytes and the natural presence of the mycorrhizae associated with the phorophytes. Therefore, felling of the phorophytes for this orchid will reduce the population of the orchid and threaten its survival.

Research attention needs to be focused on the study of many of the other highly diverse Nigerian orchid flora for their phorophyte specificity, effects of altitudinal gradients, mycorrhizal associations and habitat preferences, among other environmental factors, in order to preserve, understand and enjoy these unique Nigerian orchid species.

\section{REFERENCES}

Barkman, J.J. (1958). Phytosociology and Ecology of Cryptogamic epiphytes. Assen, The Netherlands, 628pp.

Benzing, D.H. (1998). Vulnerabilities of tropical forests to climate change: The significance of resident epiphytes. Climate Change 39: 519-540.

Borokini, T.I., A.U. Okere, A.O. Giwa, B.O. Daramola \& W.T. Odofin (2010). Biodiversity and conservation of plant genetic resources in Field Genebank of the National Centre for Genetic Resources and Biotechnology, Ibadan, Nigeria. International Journal of Biodiversity and Conservation 2(3): $37-50$

Ellwood, M.D.F., D.T. Jones \& W.A. Foster (2002). Canopy ferns in lowland dipterocarp forest support a prolific abundance of ants, termites and other invertebrates. Biotropica 34(4): 575-583.

Gravendeel, B., A. Smithson, F.J.W. Slik \& A. Schuiteman (2004). Epiphytism and pollinator specialization: drivers for orchid diversity? Philosophical Transactions of the Royal Society B: Biological Sciences 359: 1523-1535.

Hammer, Ø., D.A.T. Harper \& P.D. Ryan (2001). PAST: Paleontological Statistics Software Package for Education and Data Analysis. Palaeontologia Electronica 4(1): 9pp. <http://palaeo-electronica.org/2001_1/past/issue1_01. $h \mathrm{tm}>$

Hietz, P. (1999). Diversity and conservation of epiphytes in a changing environment. Pure Appl. Chem. 70: 2114 Available from http:/uipac.org/symposia/proceedings/ phuket97/hietz.html (accessed February, 2006).

Jayeola, A.A. (1991). Computer-aided taxonomic study of the angraecoid orchids of Nigeria and Cameroon. PhD Thesis. Obafemi Awolowo University, 16-91pp.

Koopowitz, H., P.S. Lavarack \& K.W. Dixon (2003). The nature of threats to orchid conservation, pp. 25-42. In: Dixon, K.W., S.P. Kell, R.L. Barrett \& P.J. Cribb (eds). Orchid Conservation. Natural History Publications (Borneo), Kota Kinabalu.

Kres, W.J. (1986). The systematic distribution of vascular epiphytes: an update. Selbyana 9: 2-22.

Kromer, T. \& S.R. Gradstein (2003). Species richness of vascular epiphytes in two primary Forests and fallows in the Bolivian Andes. Selbyana 24: 190-195.

Madison, M. (1977). Vascular epiphytes: their systematic occurrence and salient features. Selbyana 2: 1-13.

Moffett, M.W. (2000). What's "Up"? A critical look at the basic terms of canopy biology. Biotropica 32(4a): 569-596.

Monteiro, J.A.F., G. Zotz \& C. Körner (2009). Tropical epiphytes in a CO2-rich atmosphere. Acta Oecologica 35: 60-68. 
Nadkarni, N.M. (1984). Epiphyte biomass and nutrient capital of a neotropical elfin forest. Biotropica 16(4): 249-256.

Richards, P.W. (1996). The Tropical Rain Forest—2 $2^{\text {nd }}$ Edition. Cambridge University Press, Cambridge, UK, 450pp.

Riofrio, L., C. Naranjo, I.M. Iriondo \& E. Torres (2007). Spatial structure of Pleurothallis, Masdevallia, Lepanthes and Epidendrum epiphytic orchids in a fragment of Montane cloud forest in south Ecuador. Lankesteriana 7(1-2): 102 106.

Roberts, D.L. \& K.W. Dixon (2008). Orchids. Current Biology 18: R325-R329.

Roberts, D.L., L.M Gardiner \& M. Motes (2008). Vanda longitepala (Orchidaceae): a new species from Burma. Kew Bulletin 63: 495-497.

Segerback, L.B. (1983). Orchids of Nigeria. A.A. Balkema Publishers. A member of Swets and Zeitlinger Publishers. Netherlands, $111 \mathrm{pp}$.

Stewart, J. (1975). Aerangis biloba (Lindl.) Schultr. The Orchid Review 12 (134): 366-369.
Trapnell, D.W. \& J.L. Hamrick (2006). Variety of phorophyte species colonized by the neotropical epiphyte, Laelia rubescens (Orchidaceae). Selbyana 27(1): 60-64.

Turner, I.M., H.T.W. Tan, Y.C. Wee, A.B. Ibrahim, P.T. Chew \& R.T. Corlett (1994). A study of plant species extinction in Singapore: Lessons for the conservation of tropical biodiversity. Conservation Biology 8: 705-712.

Werner, F.A., J. Homeier \& S.R. Gradstein (2005). Diversity of vascular epiphytes on isolated remnant trees in the montane forest belt of southern Ecuador. Ecotropica 11: 21-40.

Wikipedia (2010). Orchid mycorrhiza. Available at: http:// en. wikipedia.org/w/index.php?oldid=399892921. Accessed 11th March 2011.

Wolf, J.H.D. \& A. Flamenco (2003). Patterns in species richness and distribution of vascular epiphytes in Chiapas, Mexico. Journal of Biogeography 30: 1689-1707. 